Mansoura University

Faculty of Education

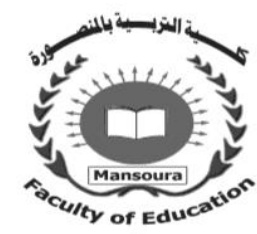

\title{
A Collaborative Blended Learning Environment for Enhancing Higher Education Students' EFL Academic Writing and Their Writing Motivation
}

\author{
By \\ Dr.Samah Mohamed Abd El Samad Ramadan \\ A Lecturer of EFL at Mansoura Higher Institute for \\ Engineering and Technology
}

Journal Of The Faculty Of Education-Mansoura University No. 112 - Oct. 2020 


\title{
A Collaborative Blended Learning Environment for Enhancing Higher Education Students' EFL Academic Writing and Their Writing Motivation
}

\author{
Dr.Samah Mohamed Abd El Samad Ramadan \\ A Lecturer of EFL at Mansoura Higher Institute for \\ Engineering and Technology
}

\begin{abstract}
This study aimed at enhancing higher education students' EFL academic writing skills and their writing motivation through using a collaborative blended learning environment. To fulfill this purpose, two instruments were constructed; a pre-post EFL academic writing skills test in addition to a writing rubric and a pre - post writing motivation scale. The participants of the study were sixty first year higher education students from Mansoura Higher Institute for Engineering and Technology. The study adopted the quasi-experimental design using two groups: the experimental group was taught through the proposed collaborative blended learning environment while the control group studied through the regular instructional methods. Results of the study revealed that the experimental group students' EFL academic writing skills were significantly enhanced and they outperformed their control group counterparts in their performance on these targeted skills in addition to enhancing their EFL writing motivation. It was recommended that collaborative blended learning enviroment should be used in EFL teaching to enhance EFL writing skills and other language skills. In addition, EFL learners should be provided with EFL academic writing skills courses in which collaborative blended learning environment is employed.
\end{abstract}

Key words: Blended Learning - Collaborative Learning - Collaborative Blended Learning Environment - Academic Writing Skills - Writing Motivation 


\section{1- Introduction:}

Effective EFL teaching and learning ensures the importance of enhancing students' EFL writing skills as writing is the primary basis upon which one's work, learning and intellect will be judged. Writing, helps learners to communicate their ideas effectively. It is difficult to develop higher education students' EFL academic writing skills and motivation. Therefore, educators must use the suitable technique to help their students be more motivated in their EFL writing classes. New technologies encourage EFL learners to work collaboratively expressing their thoughts and ideas in a written form motivationally.

Writing is one of the major English language skills which is regarded as the visual presentation of language that helps learners to communicate and understand the relation between the parts of the language and how they go together. In addition, many learners learn and remember more through the written words. Writing can be a powerful instrument of thinking because it provids learners with a mean of gaining control over their thoughts. It shaps their perception of themselves and of the world (Lindsay, $2000 \&$ Millrood, 2001).

Some researchers such as (Bassett, Devine, Perry \& Rueth,2001; Gouty \& Lid,2002; Hopkins ,2002; Kowalewski,2002; Masood,2005; Naeem,2007; Selim ,2008; Abu Armana,2011; Elnagar,2016; \& Ramadan,2017) focused on enhancing learners' EFL writing skills in different stages through using different theories and strategies. Their studies indicated the weaknesses of learners' EFL writing skill at all levels. They also suggested using different programs for improving learners' EFL writing skills (e.g. authentic materials, personalized activities, remedial program and internet based activities).

Academic writing is a type of writing that is specifically used for academic purposes (Yakhontova, 2003). Paper, journal article, thesis, and dissertation are examples of academic writings. They are developed in specific standards and refer

to certain formats of writing. Academic writings are useful for academic fulfillment, academic development, and self-actualization in academic area (Rao, 2007). More specifically, academic writing is important to understand students' disciplines, support the students' learning and establish the students' career. In the process of academic writing, there are some requirements that students should fulfil inorder to theories and use logical thinking to come up with theoretical truth (Yakhontova, 2003). 
Rao (2007) mentioned the importance of writing in EFL context as it motivates students to organize ideas, analyze, criticize and develop the ability to summarize. In addition, it strengthens students' ability in reflecting, thinking, and learning the language. Writing specifically helps the students produce the language by developing and connecting the ideas in writing product. They may analyze, criticize and summarize the topic or theme being discussed. Since writing is a productive skill, it makes students to be creative and critical in composing the language.

A number of studies were conducted in higher education to show the reasons of academic writing problems such as (Thananart,2000; Hailemariam,2011;\& Abdulkareem,2013). Resultes of these studies indicated that problems in academic writing included grammatical structure, transition signals, verb forms, and word choice. They also found that the difficulties in developing academic writing include vocabulary, spelling, structure of sentences, and idea development. Vocabulary is the most problems faced by the students in developing academic writing followed by spelling, structure of sentences, and idea development.

Learners' EFL academic writing skills are affected by some psychological elements; such as students' self-esteem, self-confidence, anxiety, motivation andself-efficacy. Motivation will be handled as one of variables in the current study as it plays as it plays an essential role in encouraging EFL learners to write and express their thoughts and ideas in a written form.

(Brown,2000; Gardner,2006;\& Gardner,2010) viewed motivation as the combination of effort and desire to achieve success in language learning. Language teachers often believe that the absence of motivation is the main reason of EFL learners' failure because motivation is one of the three main factors influencing any language acquisition. Therefore, Loewen and Reinders (2011) defined motivation as a psychological construct which refers to one's desire and incentive to be engaged in a specific activity. According to (Dornyei, 2003) writing motivation is the activation which gives more effort to writing activities memory retrieval, goal setting, planning, problem solving and evaluation. It concentrates on the relationship between the writing activity and the writing outcome. Writing motivation can be intrinsic or extrinsic. Intrinsic writing includes one's desire to make documentation, to express emotions, to satisfy creation urge and to master over writing achievement. Extrinsic writing motivation refers to one's desire to write to be loved, to be recognized by others and to avoid punishment 
Some studies such as (Crystal ,2003; Dornyei,2005; Guillautaux and Dörnyei ,2008; \& Khodashenas, Amouzegar, Farahani, Hasheminasab \& Kazemian,2013) were conducted to investigate the role of motivation in EFL learning and teaching and its effect on enhancing learners' achievement. Results indicated the influential role of motivation in all aspects of language learning in general and in developing language skills, specially reading and writing. More recently, Zhang and Guo (2013) analyzed the relationships between EFL writing and domain-specific motivation. Results indicated that EFL motivation to write and EFL writing proficiency were positively and significantly correlated with each other in addition to having great effect on enhancing EFL writing skills.

Concerning EFL teaching and learning in higher education, the traditional classroom teaching has expanded to include various levels of blending as language learning can be seen to benefit from a thoughtful integration of both classroom learning and online learning, with the strengths of both blended into a unique and

effective learning experience (Garrison \& Kanuka, 2004; Glazer, 2011; Lim \& Morris, 2009; MacDonald, 2008; Moskal \& Cavanagh, 2014). For teachers and instructors in higher education, blended learning can enhance pedagogical richness through various educational possibilities in creating the best mixture of onsite and online learning for each course and set of learning outcomes (Mortera-Gutiérrez, 2006; Stein \& Graham, 2014). In higher education in general, rationales for blended learning have been argued to include supporting flexibility and diversity, enhancing the learning experience, engaging students outside the classroom as well as increased efficiency and cost-effectiveness (Graham, Allen \& Ure, 2005; Sharpe, Benfield, Roberts \& Francis, 2006).

Accordingly, the current study proposed a collaborative blended learning environment for enhancing higher education students' EFL academic writing skills and motivation. This enviroment was designed based on the principles of the the social constructivism theory which indicates that learning is an active process where learners discover and construct their principles, concepts and facts for themselves. This theory emphasizes reciprocal teaching, peer collaboration, web quests, anchored instruction and other methods that involve learning with others. In addition, it introduces instructors as facilitators not as teachers (Bauersfeld, 1995; Wetsch,1997; Shunk,2000 and Christie,2005). 


\section{Collaborative Blended Learning Environment}

The need to develop EFL teaching and learning experiences motivated researchers to develop modern education technologies to provide education practices with more time and resources pressed on developing, deploying and implementing newly innovated technologies enhancing learning environments (cf. ebooks, e-library,e-exams, and e-school). One of these modern technologies is blended learning which combins the strengths of both face to face and online approaches for teaching and learning.

Blended learning means a combination of online and face-to-face tutoring. As Graham (2005) maintained, this could mean using the best of the best online learning to enable classroom activities to be active and engaging learning experiences. The aim was to encourage learners to be active participants in their learning processes rather than passive recipients by using online technologies to enable or support learning activities that continue outside the lecture hall, classroom or lab (extra-curricular) and encourage them to arrive in class well prepared.

Some studies confirmed the advantages of blended EFL learning such as (Oblender,2002; Gamble,2005; \& Milheim,2006). These studies revealed that blended learning leads to expanding and improving learners' learning experiences. They also revealed some of the advantages of blended learning like; immediate feedback for learners, face-to-face interaction with the teacher during learning, and the flexibility of handling different content subjects according to the available circumstances.

Some other studies had examined the effect of blended learning on EFL writing skills. For example, (Miyazoe \& Anderson,2010; Larsen ,2012; So \& Lee ,2013; Ho \& Savignon,2013; Liu,2013; \& Ramadan;2020). These studies proved the effectiveness of using the blended learning approach in improving EFL learners' writing skills at various academic levels. Results indicated that blended learning had helped increase social interaction among the learners, aided them to be more motivated and autonomous learners. 
Blended learning Environment (BLE) is described as a teaching and learning environment using both traditional and innovative digital instructional resources which conform to technological, methodical and didactic (Prohorets \& Plekhanova, 2015). Moreover, BLE is the kind of teaching and learning environment characterised by student self-regulation, the considerable students' autonomy and experiences, an unlimited learning place, time and physical materials (Singer \& Stoicescu, 2010). It also offers students great control over time to when what and how to study (Bonk \& Graham, 2006; Jokinen \& Mikkonen, 2013), as such, it is termed to be a time blending learning environments. The blending of instructional objectives, strategies and the condition of online resources of teachers play a significant role in designing (Akkoyunlu \& Soylu, 2008). The learning process in BLE concentrates on implementing designed and agreed to learn objectives through innovative instructional technologies adapted to transfer skills and knowledge in real time. In support of that scholars have argued that students who actively engage on BLEs tend to achieve higher grades compared to traditional teaching and learning environments because they interact, participate and share in well-designed educational environments with enhanced content. However, trends in the use of computer-aided technologies in teaching and learning (cf., e-learning, Internet, mobile learning, blended learning, online learning) has increased the number of universities enjoying its potential advantages (Makuu \& Ngaruko, 2014).

Collaborative learning is an instructional method in which learners are teamed together. Collaborative learning has several advantages such as increasing self-esteem and motivation among learners, improving complex and cognitive thinking, creating positive feelings among learners and about school, and making responsible learners (Jacobs, Power \& Loh, 2002). In addition, Maheady, Harper, Mallette \& Karnes (2004) proved the effect of collaborative learning on learners' achievement. The result of this research indicated that elementary school learners learn better when they teach one another than they do in completely teacher-directed classrooms. With regard to (Nakatsukasa,2009; Srijongjai,2013) collaborative feedback activities are very effective when they are conducted in a blended learning setting. Findings indicated that learners have positive perception towards collaborative feedback activities used in face-to-face and online environments. 
Collaborative blended learning (CBL) according to Vygotsky's (1978) social constructivism is the roots of CBL stressed on learners working together in online learning environments to create new knowledge collaboratively and authentically (Sharpe, Benfield, Roberts, \& Francis, 2006; Doolan et al. ,2006), echoing Vygotsky, suggested that CBL provided the opportunity for interaction in the form of learner-to-learner support, enabling learners to share ideas and provide feedback to each other on learning-related activities in diverse locations. CBL offers opportunitiesfor all learners to participate actively in critical reflection and discourse, and contribute to a flexible and sustainable community of inquiry (Vaughan, 2010; Garrison, 2011). CBL can provide learners with the opportunity to practice conflict negotiation and consensus building as learners exchange ideas, share perspectives and arguments, and use previous knowledge or experiences to solve problems in group work activities (Dewiyanti et al., 2007).

To conclude, in light of the previously mentioned literature review, it becomes essential for teachers and lecturers to pay attention to the growing needs of the higher education students to write correctly. Hence, this study was established with an aim of enhancing higher education students' EFL academic writing skills and motivation to write using modern technology. A collaborative blended learning environment is able to motivate EFL learners to write correctely. Thus, the current study aimed at investigating the effectiveness of using a collaborative blended learning enviroment in enhancing higher education students' EFL academic writing skills and their writing motivation.

\section{The Pilot Study}

A pilot study was conducted to document the current level of EFL academic writing skills and writing motivation of first year higher education students $(\mathrm{N}=30)$ from Mansoura Higher Institute for Engineering and Technology. The following tables reports the pilot results. 
Table (1)

Results of the Pilot Study EFL Academic Writing Skills Test

\begin{tabular}{|c|c|c|c|c|}
\hline $\begin{array}{c}\text { Institutio } \\
\mathrm{n}\end{array}$ & Academic Writing Skills & $\begin{array}{r}\mathrm{M} \\
\text { ean }\end{array}$ & $\begin{array}{c}\mathrm{S} \\
\mathrm{D}\end{array}$ & $\begin{array}{l}\text { Precent } \\
\text { age }\end{array}$ \\
\hline & Cohesion and Unity & 1.5 & 0.763 & $51 \%$ \\
\hline $\begin{array}{l}\text { Mansoura } \\
\text { Higher }\end{array}$ & Grammatical accuracy & 1.76 & 0.523 & $5 \wedge \%$ \\
\hline Institute & Use correct Mechanics & $1 . \varepsilon 0$ & 0.702 & $4 \wedge \%$ \\
\hline $\begin{array}{l}\text { For } \\
\text { Engineerin }\end{array}$ & Vocabulary control & 1. $\{\wedge$ & 0.707 & $49 \%$ \\
\hline g & Coherence & $1 . r 8$ & 0.701 & $\leqslant 7 \%$ \\
\hline $\begin{array}{l}\text { and } \\
\text { Technolog }\end{array}$ & Forming clearly structured sentence & 1.06 & 0.524 & $5 r \%$ \\
\hline $\mathrm{y}$ & Total & 9.15 & 0.701 & $50.6 \%$ \\
\hline
\end{tabular}

Results in Table (1) show that the percentage of students' score on the EFL Academic Writing Skills Test is (50.6\%). This means that those students need more improvement to be better and to enhance their EFL academic writing skills.

Table (2)

$\frac{\text { Pilot Study EFL Writing Motivation Scale Results }}{\text { Domain }}$

\begin{tabular}{ccccc} 
Domain & $\begin{array}{c}\text { Mea } \\
\text { n Score }\end{array}$ & $\begin{array}{c}\text { Per } \\
\text { centage }\end{array}$ \\
\hline $\begin{array}{c}\text { Writing } \\
\text { Motivation }\end{array}$ & 18.2 & & $\% 5$ \\
\hline
\end{tabular}

Results in Table (2) show that the percentage of Students' Mean score on the pilot study EFL writing motivation scale was (\%59). This means that those students needed more improvement to enhance their EFL writing motivation.

\section{Statement of the Problem}

Based on the previous review, the researcher's experience as an EFL instructor and the pilot study results, first year higher education students need to enhance their EFL academic writing skills and their writing motivation. Thus, the current study aimed at investigating the effectiveness of using a collaborative blended learning environment in enhancing first year higher education students' EFL academic writing skills and their writing motivation.

\section{Questions}

The present study attempted to answer the following main question:

"To what extent can a collaborative blended learning enviroment enhance first year higher education students' EFL academic writing skills and their motivation?"

For research purposes, the following sub-questions were derived from the main question. 
What are the components of the proposed collaborative blended learning enviroment required for enhancing first year higher education students' EFL academic writing skills and their motivation?

What is the effectiveness of using a collaborative blended learning environment in enhancing first year higher education students' EFL academic writing skills?

What is the effectiveness of using a collaborative blended learning environment in enhancing first year higher education students' EFL writing motivation?

Purpose

The present study aimed at:

Enhancing first year higher education students' EFL academic writing skills and their writing motivation through using a collaborative blended learning environment.

Hypotheses

This study tested the following hypotheses:

There is a statistically significant difference at $(0.05)$ level between the mean score of the control group and that of the experimental one on the post administration of the EFL academic writing skills test in favor of the experimental group.

There is a statistically significant difference at (0.05) level between the mean scores of the experimental group on the pre-post administration of the EFL academic writing skills test in favor of the post one.

1) There is a statistically significant difference at (0.05) level between the mean score of the control group and that of the experimental one on the post administration of the EFL writing motivation scale in favor of the experimental group.

2) There is a statistically significant difference at (0.05) level between the mean scores of the experimental group students on the pre-post administration of the EFL writing motivation scale in favor of the post one.

\section{Definition of Terms}

\section{Writing Skills}

In this study writing refers to the ability to organize ideas into a comprehensive text wih agrammatical accuracy and precis word choice. Academic Writing includes some sub- skills such as forming clearly structured sentences, cohesion and unity, grammatical accuracy, use correct mechanics, vocabulary control and coherence. Writing Motivation 
In this study writing motivation is considered as having a vital desire affecting students' ability to do writing tasks collaborativelly expressing their desires and achieving their goals through using Google classrooms and Google docs as motivational collaborative blended learning environment tools.

Blended Learning (BL)

In this study, blended learning is defined as the combination of collaborative face-to-face learning and collaborative online learning to enhance students' EFL academic writing skills and their writing motivation.

Collaborative Learning ( CL)

For the purpose of this study collaborative learning (CL) is defined as grouping students for achieving their learning goals such as doing writing tasks or giving a summary of a text.

Collaborative Blended Learning Environment (CBLE)

For the purpose of this research (CBLE) is defined as a learning environment in which Istudents can collaborate in groups inside the classroom and online using some collaborative blended learning tools to enhance their EFL academic writing skills and their EFL writing motivation via using; Google collaborative classrooms, Google Docs, Google Forms, Gmail and Google Hangout.

Method

Design

The study adopted the quasi-experimental design using two groups: experimental and control. The experimental group received the target four modules by using the proposed collaborative blended learning environment, while the control group received them by using regular instruction. Both groups received the pre- post EFL academic writing skills test to assess their taregeted EFL academic writing skills. They also received the pre-post writing motivation scale as well.

Participants 
Participants of the study were sixty first year higher education students from Mansoura Higher Institute for Engineering and Technology. They were trained on using the proposed collaborative blended learning environment tools ; thus, it was expected that they would be qualified to use some Google collaborative tools (such as; Google account "Gmail”, Google Classrooms, Google forms and Google Docs) through which the proposed collaborative blended learning environment was presented. Participants were divided into two groups: control and experimental, and each group consisted of 30 students. The experimental group students were taught through the proposed collaborative blended learning ennironment, while the control group students studied through regular instruction.

\section{Instruments}

The following instruments were designed and used:

1) An EFL academic writing skills questionnaire to determine the necessary EFL academic writing skills for the first year higher education students.

2) A pre-post EFL academic writing skills test in addition to a writing scoring rubric.

3) A pre-post EFLwriting motivation scale.

\section{The Collaborative Blended Learning Environment}

After reviewing the literature on collaborative learning, blended learning, EFL academic writing skills and motivation to write, the collaborative blended learning environment was constructed. This environment was designed based on the principles of the social constructivism theory. Those principles were reflected throughout the application of the target modules as students were able to collaborate, interact, share ideas and thoughts and give feedback.

The environment employed some google cloud collaborative tools namely; Google Account “ Gmail”, Google classrooms, Google Docs, Google Forms and Google Hangout. The Google cloud collaborative tools were used as follows:

- Google account "Gmail" was used to enable the instructor to use all the Google collaborative tools. Each student would receive an invitation to use the proposed environment. S/he would be asked to login using her/his Google account and password. In addition, it was used to enable the instructor and the students to send and receive email.

- Google classroom was used to create and design a collaboratiove blended learning environment (https://classroom.google.com/c/Mzc5NjgyMzk4MDBa) 
- Google Hangout was used to create a closed group named" English Language 1" to help students communicate with each other and with their instructor, as well. This group gave the instructor and the students the chance to chat together.

- Google Docs was used to present the writing assignments as the students were able to collaborate, share ideas and thoughts, edite and give feedback.

- Google forms was used to create online quizzes for assessing the students' EFL academic writing skills during and after each module.

The general aims of designing the collaborative blended learning environments were to encourage students to write, present several writing assignments addressing students' individual differences, give the students the chance to write collaboratively using different ways and enhance the students' EFL writing motivation.

\section{Specific Objectives}

These objectives specify what students were expected to achieve as an outcome of teaching through the proposed collaborative blended learning environment. These objectives were; use correct mechanics, produce grammatical accuracy, choose suitable vocabulary, formulate clearly structured sentences, use cohesive devices properly and improve their EFL writing motivation.

\section{The Experimental Treatment}

An quasi-experimental design with one experimental group and one control group was used in the present study. The experiment took place in Mansoura Higher Institute for Engineering and Technology. The experimental treatment was carried out through using Google collaborative tools. The proposed collaborative blended learning environment was presented in five academic writing modules adopted from (Academic Writing A Handbook for International Students $3^{\text {rd }}$ Edition) in addition to an introductory module. The introductory module was implemented in the computer lab. It lasted for two sessions. The proposed environment was administered during the first semseter of 2020-2021 academic year . Following-up on the students and giving them feedback was done face to face inside the classroom and online through the collaborative blended learning environment (https://classroom.google.com/c/Mzc5NjgyMzk4MDBa).

The following steps were followed:

\section{Pre- administration}


Pre- administration was at the mid of the first semester of the (20202021) academic year. Homogeneity between the control group and the experimental group was established through administering the EFL academic writing skills test and the motivation to write scale to the participants before administering the collaborative blended learning environment.

\section{The administration}

The collaborative blended learning environment was implemented to participants of the experimental group. The control group had the regular EFL writing instructional activities. Treatment was conducted during the first semester of the (2020/2021) academic year from the mid of October up to the begining of December. The treatment lasted for six weeks, two sessions per week. Due dates for submitting the assignments were posted on the environment message board.

\section{Post- administration}

The post-administration of the instruments was conducted after the experimental treatment on Thursday $2^{\text {nd }}$ of December 2020. It was conducted to reveal the changes in first year higher education students' EFL academic writing skills and their motivation to write. The post-administration was administered on both the control and experimental groups. In addition, the experimental group assignments were assessed and the best assignments were published. So, the post- administration aimed at measuring the effectiveness of proposed collaborative blended learning environment in enhancing first year higher education students' EFL academic writing skills and their writing motivation.

\section{Results and Discussions}

The results of the study were statistically analyzed test in terms of its hypotheses and they were discussed in the light of the theoretical background and related studies. Results of the study were reported as follows:

\section{Testing the First Hypothesis}

The first hypothesis stated that "'There is a significant difference at $(0.05)$ level between the mean score of the control group and the experimental group students on the post administration of the EFL 
academic writing skills test in favor of the experimental group." T-test for independent samples was used to compare the difference between the mean scores of the experimental and control group students in the EFL academic writing skills test after implementing the proposed collaborative blended learning environment.

Table ( $($ )

Results of the Control and Experimental Groups on the Post Administration of the EFL Academic Writing Skills Test

\begin{tabular}{|c|c|c|c|c|c|c|}
\hline \multirow[t]{2}{*}{$\begin{array}{c}\text { Academic } \\
\text { Writing Skills }\end{array}$} & \multicolumn{2}{|c|}{ Control } & \multicolumn{2}{|c|}{$\begin{array}{c}\text { Experiment } \\
\text { al }\end{array}$} & \multirow[t]{2}{*}{$\begin{array}{c}\mathrm{t}- \\
\text { value }\end{array}$} & \multirow[t]{2}{*}{$\begin{array}{c}\text { Sig } \\
.\end{array}$} \\
\hline & $\begin{array}{c}\text { Mea } \\
n\end{array}$ & SD & Mean & $\mathrm{SD}$ & & \\
\hline Cohesion and Unity & 3.43 & $\begin{array}{c}0.7 \\
2\end{array}$ & 5.58 & $\begin{array}{c}0.6 \\
7\end{array}$ & 11.73 & $\begin{array}{c}0.0 \\
5\end{array}$ \\
\hline $\begin{array}{c}\text { Grammatical } \\
\text { accuracy }\end{array}$ & 3.24 & $\begin{array}{c}0.5 \\
6\end{array}$ & 5.82 & $\begin{array}{c}0.4 \\
0\end{array}$ & 20.11 & $\begin{array}{c}0.0 \\
5\end{array}$ \\
\hline $\begin{array}{l}\text { Use correct } \\
\text { Mechanics }\end{array}$ & 3.02 & $\begin{array}{c}0.7 \\
8\end{array}$ & 5.61 & $\begin{array}{c}0.5 \\
4\end{array}$ & 15.2 & $\begin{array}{c}0.0 \\
5\end{array}$ \\
\hline Vocabulary control & 1.76 & $\begin{array}{c}0.5 \\
6\end{array}$ & 3.55 & $\begin{array}{c}0.5 \\
0\end{array}$ & 12.7 & $\begin{array}{c}0.0 \\
5\end{array}$ \\
\hline Coherence & .88 & $\begin{array}{c}0.3 \\
4\end{array}$ & 1.94 & $\begin{array}{c}0.2 \\
5\end{array}$ & 13.62 & $\begin{array}{c}0.0 \\
5\end{array}$ \\
\hline $\begin{array}{c}\text { Forming clearly } \\
\text { structured sentences }\end{array}$ & 1.01 & $\begin{array}{c}0.5 \\
4 \\
\end{array}$ & 1.96 & $\begin{array}{c}0.2 \\
5 \\
\end{array}$ & 9.8 & $\begin{array}{c}0.0 \\
5\end{array}$ \\
\hline Total & \begin{tabular}{c|}
13.3 \\
4 \\
\end{tabular} & & 24.46 & & & $\begin{array}{c}0.0 \\
5 \\
\end{array}$ \\
\hline
\end{tabular}

Table (3) indicates that there is a significant difference at (0.05) between the mean scores of the control and experimental groups in the post administration of the EFL academic writing skills test in favor of the experimental group. 
Comparing the mean scores of the control and experimental group on the post administration of the EFL writing skills test shows that the experimental group students' mean score in the post EFL writing skills test are $(3.43,3.24,3.02,1.76,0.88$ and 1.01 respectively), while the group's mean score in the post EFL writing skills test are (5.58, 5.82, 5.62, 3.55, 1.94 and 1.96 respectively). These values indicate the significant enhancement of the experimental group students concerning their EFL academic writing subskills over the control group. This implies the effect of the proposed collaborative blended learning environment on first year higher education students' EFL academic writing skills. Thus, the first hypothesis is verified and accepted.

\section{Testing the Second Hypothesis}

The second hypothesis stated that " There is a significant difference at (0.05) level between the mean score of the experimental group students on the pre-post administration of the EFL academic writing skills test in favor of the post one." T- test for independent samples was used to compare the difference between the mean score of the experimental in the pre-post EFL academic writing skills test.

Table (4)

Results of the Experimental Groups on the Pre-post Administration of The EFL Academic Writing Skills Test

\begin{tabular}{|c|c|r|r|r|r|r|}
\hline \multirow{2}{*}{$\begin{array}{c}\text { Academic } \\
\text { Writing Skills }\end{array}$} & \multicolumn{2}{|c|}{$\begin{array}{c}\text { Pre- } \\
\text { administeration }\end{array}$} & \multicolumn{2}{c|}{$\begin{array}{c}\text { Post- } \\
\text { administeration }\end{array}$} & $\begin{array}{r}\text { t- } \\
\text { value }\end{array}$ & g. \\
\cline { 2 - 5 } & Mean & SD & Mean & SD & & \\
\hline Cohesion and unity & 3.00 & .83 & 5.56 & .67 & 14.4 & 0. \\
& & & & & & 01 \\
\hline Grammatical acurracy & 2.90 & .92 & 5.80 & .40 & 16.5 & 0. \\
& & & & & & 01 \\
\hline Use correct mechanics & 2.63 & .80 & 5.6 & .54 & 16.6 & 0. \\
& & & & & & 01 \\
\hline Vocabulary control & 1.86 & .50 & 3.53 & .50 & 12.8 & 0. \\
& & & & & & 01 \\
\hline Coherence & .70 & .46 & 1.93 & .25 & 13.4 & 0. \\
& & & & & & 01 \\
\hline $\begin{array}{c}\text { Forming clearly } \\
\text { structured sentence }\end{array}$ & .70 & .53 & 1.93 & .25 & 13.4 & 0. \\
\hline Total & 11.79 & & 24.35 & & & 0. \\
\hline
\end{tabular}


Comparing the mean score in the pre- post application of the writing test reveal that the experimental group students' mean score in the overall pre writing test is (11.79), however their mean score in the overall post writing test is (24.35). These values indicate the significant difference between the mean scores before and after implementing the EFL academic writing skills test in favor of the post one.

The greater mean score of the experimental group's post-test implies that the experimental group students' level in overall EFL writing skills test enhanced due to the proposed collaborative blended learning environment and the extra collaborative writing assignments such as write a summary of story, write a report and write an essay. This increase indicates the effect of the proposed collaborative blended learning environment. Such results of the present study show that the experimental group achieved more improvement on the post administration of the EFL academic writing skills test compared to the pre-test. This result is consistent with Miyazoe and Anderson (2010), Larsen (2012), So and Lee (2013), Ho and Savignon, (2013) and Liu (2013). These studies proved the effectiveness of using the blended learning approach in enhancing EFL learners' writing skills at various academic levels. These studies concluded that students mostly have positive perception towards the usefulness of blended learning in enhancing their EFL writing skills. Results also showed that blended learning had helped increase social interaction among the students, aided them to be more motivated and autonomous learners, decreased their communication anxiety and enhanced their EFL writing skills. Accordingly, the second hypothesis of the present study is proved and verified.

\section{Testing the third hypothesis}

The third hypothesis stated that "There is a significant difference at (0.05) level between the mean score of the control group and the experimental group students on the post administration of the writing motivation scale in favor of the experimental group." T-test for independent samples was used to compare the difference between the mean scores of the control and experimental group students in the post administeration of the EFL writing motivation scale as shown in the following Table (5).

Table (5)

Results of the Control and Experimental Groups on the Post Administration of the EFL Writing Motivation Scale

\begin{tabular}{|c|c|c|c|c|c|c|}
\hline \multirow[t]{2}{*}{ Domains } & \multicolumn{2}{|c|}{ Control Group } & \multicolumn{2}{|c|}{ Experimental Group } & \multirow[t]{2}{*}{ t-value } & \multirow[t]{2}{*}{ Sig. } \\
\hline & Mean & $\mathrm{SD}$ & Mean & $\mathrm{SD}$ & & \\
\hline
\end{tabular}




\begin{tabular}{|l|l|l|l|l|l|l|}
\hline Writing Motivation & 54.73 & 7.44 & 120.83 & 3.41 & 44.19 & 0.05 \\
\hline
\end{tabular}

Table (5) indicates that there is a significant difference at (0.05) level between the mean score of the control and experimental groups in the post administration of the EFL writing motivation scale. T-value is (44.19) and it is significant at $(0.05)$ level.

Comparing the mean scores of the experimental and control group on the post administration of the EFL writing motivation scale shows that the experimental group students' mean score in the post EFL writing motivation scale is (120.83), while the control group's mean score in the post EFL writing motivation scale is (54.73). These values indicate the significant enhancement of the experimental group students concerning their EFL writing motivation over the control group. This implies the effect of the proposed collaborative blended learning environment on enhancing first year higher education students' EFL writing motivation. Based on results shown in the previous Table (5), the third hypothesis of the study is proved and accepted.

\section{Testing the fourth hypothesis}

The fourth hypothesis stated that " There is a significant difference at (0.05) level between the mean score of the experimental group students in the pre and post administration of the EFL writing motivation scale in favor of the post one." Results are presented in the following table. T-test for independent samples was used to compare the difference between the mean score of the experimental group students before and after the administeration of the EFL writing motivation scale as shown in the following Table (6).

Table (6)

Results of the Experimental Groups on the Pre-post Administration of the EFL Writing Motivation Scale

\begin{tabular}{|c|c|c|c|c|c|c|}
\hline \multirow[t]{2}{*}{ Domains } & \multicolumn{2}{|c|}{$\begin{array}{c}\text { Pre- } \\
\text { administration }\end{array}$} & \multicolumn{2}{|c|}{$\begin{array}{c}\text { Post- } \\
\text { administration }\end{array}$} & \multirow[t]{2}{*}{-value } & \multirow[t]{2}{*}{ ig. } \\
\hline & ean ${ }^{M}$ & D & ean $^{M}$ & D & & \\
\hline $\begin{array}{l}\text { Writing } \\
\text { Motivation }\end{array}$ & $3.46^{5}$ & .67 & $0.83^{12}$ & .41 & 7.29 & .05 \\
\hline
\end{tabular}


Table (6) illustrates that t-value for the pre and post administration of the EFL writing motivation scale is (57.29) and it is significant at (0.05) level. Comparing the mean score in the pre- post administration of the EFL writing motivation scale shows that the experimental group students' mean score in the pre- EFL writing motivation scale is (53.46), while their mean score in the post administration of the EFL motivation to write scale is (120.83). These values indicate a significant difference between the mean score before and after the administration. This means that students' EFL writing motivation was increased because of using the proposed collaborative blended learning environment. Therefore, the fourth hypothesis of the study is verified and accepted.

Such results of the present study show that the experimental group achieved more improvement on the post administration of the EFL writing motivation scale compared to the pre-test. This result is consistent with Gedera (2011) which showed the effect of using weblog as a tool of improving the language skills of pre-university ESL students in Malaysia. It also discussed the impact of weblog activities on students' motivation to write in English. Results proved the benefits that can be acquired as a result of the integration of weblog in language learning classrooms in general and writing skills in particular.

\section{The Effectiveness of the Proposed Environment}

First, eta square $(\eta 2)$ was estimated to measure the effect size of the proposed collaborative blended learning environment on the students' EFL academic wrriting skills. Eta square ( $\eta 2$ ) was estimated after calculating the t-value. the formula was: $\eta^{2}=\frac{t^{2}}{t^{2}+d f}$. The following table illustrates the effect size of the proposed collaborative blended learning environment on the experimental group students' EFL academic writing skills.

\section{Table (7)}

Level of the Effect Size of the Proposed Environment on the Students' EFL Academic Writing Skills

\begin{tabular}{|l|l|l|l|l|l|l|l|}
\hline Domain & Writing skills & alue & 2 & $2+(\mathrm{n}-1)$ & 2 & fect size & ffect \\
\hline $\begin{array}{l}\text { The } \\
\text { proposed } \\
\begin{array}{l}\text { Collabor } \\
\text { ative } \\
\begin{array}{l}\text { Blended } \\
\text { Learning }\end{array}\end{array}\end{array}$ & Cohesion and unity & 4.4 & 7.36 & 36.36 & .87 & 87 & igh \\
\cline { 2 - 9 } & Grammatical accuracy & 6.5 & 2.25 & 01.25 & .90 & 90 & igh \\
\cline { 2 - 9 }
\end{tabular}




\begin{tabular}{|l|l|c|c|c|c|c|c|}
\hline $\begin{array}{l}\text { Environ } \\
\text { ment }\end{array}$ & Vocabulary control & 2.8 & 3.84 & 92.84 & .84 & 84 & igh \\
\cline { 2 - 8 } & Coherence & 3.4 & 9.56 & 08.56 & .94 & 94 & igh \\
\cline { 2 - 8 } & $\begin{array}{c}\text { Form clearly } \\
\text { structured sentenc }\end{array}$ & 3.4 & 9.56 & 08.56 & .94 & 94 & igh \\
\hline
\end{tabular}

Results in Table (7) illustrate the eta square $(\eta 2)$ for each writing subskill. The effect size values are $(0.87,0.90,0.90,0.84,0.94$ and 0.94 respectively). It is obvious that all of these values exceeded (0.14) which reflects a high effect size for all the target writing skills.

The effect size arranged between (0.84 and 0.9) for the target EFL academic writing skills points to the high effect of the experimental treatment in this study. Thus, proposed collaborative blended learning environment enhanced EFL higher education students' EFL academic writing skills magnificently.

Second, eta square ( $\eta 2)$ value was estimated to determine the effect size of the proposed collaborative blended learning environment on the students' EFL writing motivation. Results are illustrated in the following table.

Table (8)

Level of the Effect Size of the Proposed Environment on the Students' EFL Writing Motivation

\begin{tabular}{|c|c|c|c|c|c|c|c|}
\hline \begin{tabular}{|c|} 
Independent \\
Variable
\end{tabular} & \begin{tabular}{|l|} 
Dependent \\
Variable
\end{tabular} & $\mathrm{T}$ & $\overline{t 2}$ & $\begin{array}{c}\mathrm{t} 2+(\mathrm{n}- \\
1)\end{array}$ & $\overline{\eta 2}$ & \begin{tabular}{|l|} 
The \\
Effect \\
size
\end{tabular} & $\begin{array}{l}\text { The } \\
\text { Effe } \\
\text { ct }\end{array}$ \\
\hline \begin{tabular}{c|} 
The \\
collaborati \\
ve blended \\
learning \\
environme \\
nt
\end{tabular} & \begin{tabular}{|l|} 
Writing \\
Motivation
\end{tabular} & $\$ 7.29$ & 3282.144 & B311.144 & 0.9912 & $99.12^{\circ}$ & High \\
\hline
\end{tabular}

Results in Table (8) illustrate the value of eta square for the motivation to write scale. The effect size value is (99.12). This value is high which reflects the effect size of the proposed collaborative blended learning environment on enhancing the experimental group students' EFL writing motivation.

The significant statistical difference between the experimental and the control groups shown in Table (6) in addition to effect size results shown in Table (8) support the effectiveness of using the proposed collaborative blended learning environment on enhancing first year higher education students' EFL writing motivation. 
To sum up, all the values of eta square ( 12$)$ mentioned in Table (7) and Table (8) are higher than (0.14) which shows the great effect of using the proposed collaborative blended learning environment on enhancing higher education students' EFL writing skills and their writing motivation.

\section{Conclusions}

The results of this research revealed the effectiveness of using collaborative blended learning enviroment in enhancing higher education students' EFL academic writing skills and their writing motivation. These results give momentum to other studies that stressed the effect of collaborative learning on learners' achievement. Nakatsukasa (2009) and Srijongjai (2013) indicated that students had positive perception towards collaborative feedback activities used in face-to-face and online environments. In addition to giving further momentum to other studies that stressed the effect of collaborative writing using Google Docs on learners' EFL writing skills. For example, Seyyedrezaie, Ghonsooly, Shahriari and Fatemi (2016) revealed that Google Docs played an effective role in improving students' writing performance.

To sum up, it was concluded that using collaborative blended learning environment could enhance higher education students' EFL academic writing skills and their writing motivation. With reference to the results of this study, the following points were revealed:

Using collaborative blended learning environment was effective in enhancing higher education students' EFL academic writing skills.

1) Using collaborative blended learning environment was effective in enhancing higher education students' EFL writing motivation.

2) A curiculum developed based on collaborative blended learning can enhance higher education students' achievement in general and their EFL academic writing skills in particular.

\section{Recommendations}

A number of recommendations based on the results and the conclusions could be made as follows:

- EFL learners should use collaborative blended learning tools to enhance their EFL academic writing skills and their writing motivation.

- EFL teachers should be trained on using collaborative blended learning environment in enhancing students' EFL academic writing skills.

- EFL Curriculum designers must take into their account the importance of embedding collaborative blended learning environment tools in the syllables of different stages.

Suggestions for further research 
The following areas are suggested for further research:

1) Using collaborative blended learning to enhance EFL learners' linguistic competence.

2) Using collaborative blended learning to enhance oral communication skills among EFL learners.

3) Enhancing other language skills among EFL learners such as reading and listening through collaborative blended learning.

4) Conducting new research to investigate the impact of collaborative learning on EFL learners' achievement.

\section{References}

AbuArmana,M.(2011). The Impact of a Remedial Program on English

Writing Skills of The Seventh Grade Low Achievers. Published MA Thesis, Faculty of Education, Gaza University.

Akkoyunlu, B., \& Soylu, M.Y. (2008). A study of student's perceptions in a blended learning environment based on different learning styles. Educational Technology \& Society, 11(1), 183-193.

Archibald, A. (2001). Targeting L2 writing proficiencies: Instructions and areas of change in students writing over.Time International Journal of English studies, 1(2).

Bassett, D. Devine, D. Perry \&Rueth, C. (2001). " Keys to Improving Writing in the Primary Grades." An Action Research Project Submitted in Partial Fulfillment of the Requirements for M.A. Degree. Illinois Chicago. Saint Xavier University. The ERIC database

Bonk, C.J., \& Graham, C.R. (Eds.). (2006). The handbook of blended learning: Global perspectives, local designs. San Francisco, CA: Pfeiffer Publishing.

Carroll, M.; Merwe, A.; Van Der, \&Kotzé, P. (2011). Secure Cloud Computing Benefits, Risks and Controls. Information Security South Africa. 1-9.

Chan, E. S. (2012). An innovative learning approach: Integrate peer-topeer learning into blended learning. International Journal of Global Education, 1.

Chang, S. Z. (2001). "Effective Remedial Programs and Instruction". Education Journal, 171.

Dewiyanti, S., Brand-Gruwel, S., Jochems, W., \& Broers, N. J. (2007). Students' experiences with collaborative learning in asynchronous computer-supported collaborative learning environments. Computers in Human Behavior, 23. 
Dillenbourg, P. (1999). Introduction: What do you mean by "collaborative learning"? In P. Dillenbourg (Ed.), Collaborative learning: Cognitive and computational approaches. Oxford, UK: Pergamon.

Doolan, M. A., Thornton, H. A., \& Hilliard, A. (2006). Collaborative learning: Using technology for fostering those valued practices inherent in constructive environments in traditional education. Journal for the Enhancement of Learning and Teaching, 3,7-17

Dornyei, Z. (2003). Attitudes, orientations, and motivations in language learning: Advances in theory, research, and applications. Language Learning, 53, 3-32.

Gamble, Valerie J. (2005). The effectiveness of blended learning for the employee. Dissertation Unpublished. Fielding Graduate University.

Garrison, D. R. (2011). E-learning in the 21st century: A framework for research and practice ( 2 ndEd.). New York, NY: Routledge.

Graham, S., \& Harris, K.R.(2000).The role of self-regulation Transcription Skills in Writing and Writing Development.Educational Psychologist, 35, 3-12.

Gouty J. and Lid. S. (2002).Improving Student Writing Ability the Use of the Teacher Intervention. Published M.A. Thesis. Illinois, Chicago. Saint Xavier University. Retrieved from ERIC database.

Heinze, A. (2008). Blended learning: An interpretive action research study. UK: University of Salford.

Ho, M. C., \&Savignon, S. J. (2013). Face-to-face and computer-mediated peer review in EFL writing.CALICO journal, 24(2), 269-290.

Hopkins, C. (2002). Improving Tenth Grade Student's Five- Paragraph Essay Writing Skills Using Various Writing Strategies, Guided Assignment, and Portfolios for Growth.Nova south eastern university. The ERIC database.

Jacobs G, Power MA andLoh WI (2002). The teacher's sourcebook fo rcooperative learning: practical techniques, basic principles, and frequency asked questions. Thousand Oaks, CA: Crown Press.Kang

Jokinen, P., \& Mikkonen, I. (2013). Teachers' experiences of teaching in a blended learning environment. Nurse Education in Practice, 13, 524528.

Jonassen, D. H., \& Kwon H., II. (2001). Communication patterns in computer mediated versus faceto-face group problem solving. Educational Technology Research and Development, 49, 35 -51.

Jung, I., Choi, S., Lim, C., \& Leem, J. (2002). Effects of different types of interaction on learning achievement, satisfaction and participation in 
web-based instruction. Innovations in Education and Teaching International, 39, 153-162.

Khampusaen, D.(2014). Teaching English Language with Cloud -Based Tools. International Journal of the Computer, the Internet and Management, 22,(1)

Shunk DH. (2000). Learning theories: An educational perspective (3rdEd). Upper Saddle River, NJ: Prentice-Hall.

Kowalewski, E. ,(2002). Improving Student Writing in the Elementary Classrooms. Saint Xavier University. The REIC database.

Larsen, L. J. E. (2012). Teacher and student perspectives on a blended learning intensive English program writing course.Unpublished Ph.D. thesis, Iowa State University.

Lindsay, P. (2000). Teaching English Worldwide: A new practical guide to teaching English. San Francisco: Alta Book Center Publisher.

Liu, M. (2013). Blended Learning in a University EFL Writing Course: Description and Evaluation. Journal of Language Teaching and Research, 4(2), 301-309.

Maheady, L., Harper, G. F., Mallette, B., \& Karnes, M. (2004). Preparing preservice teachers to implement class wide peer tutoring. Teacher Education and special education, 27(4), 408-418.

Makuu, M., \& Ngaruko, D. (2014). Innovation and development in blended learning mode in higher learning institutions: Interactive experiences from OUT's postgraduate students and instructors. Huria: Journal of the Open University of Tanzania. 18(1), 42-57.

Masood, A. (2005). Exploiting Authentic Materials for Developing Writing Skills. Published MA thesis, Pakistan, faculty of social sciences, Journal for the study of English linguistics, 1.(1)

Milheim, W. D. (2006). Strategies for the Design and Delivery of Blended Learning Courses. Educational and Delivery Technology, 46(6).

Millrood, R. (2001). Modular Course in English Teaching Methodology. Teacher Development Series.

Miyazoe, T., \& Anderson, T. (2010).Learning outcomes and students' perceptions of online writing: Simultaneous implementation of a forum, blog, and wiki in an EFL blended learning setting. System, 38(2), 185-199.

Naeem, M. (2007). A Suggested CALL Program to Develop EFL College Learners` Mechanics of Writing. Unpublished M.A. Thesis, Faculty of Education, Kafr El; Sheikh University. 
Nakatsukasa, K. (2009). The efficacy and students' perceptions of collaborative blogging in an ESL classroom. In C. A. Chapelle, H. G. Jun, \& I. Katz (Eds.), Developing and evaluating language learning materials (pp. 69-84). Ames, IA: Iowa State University.

Nunan, D. (2003). Practical English LanguageTeaching. Boston: McGraw-Hill.

Oblender, Th. (2002). A Hybrid Course Model: One Solution to the High Online DropOut Rate. Learning \& Leading with Technology, 29(6), 42-46.

Prohorets, E., \& Plekhanova, M. (2015). Interaction intensity levels in blended learning environment. Procedia - Social and Behavioral Sciences, 174, 3818-3823.

Rao, Z. (2007). Training in brainstorming and developing writing skills. ELT Journal, 61, 100-106.

Selim, M (2008). The Effectiveness of a program Based on Individualized Activities in Developing first Prep Students' writing skills and their Interest in English.Cairo University. Institue of Education Studies.

Sharpe, R., Benfield, G., Roberts, G., \& Francis, R. (2006). The undergraduate experience of blended e-learning: A review of UK literature and practice. London, UK: Higher Education Academy.

Singer, F. M., \& Stoicescu, D. (2010). Using blended learning as a tool to strengthen teaching competencies. Procedia Computer Sciences, 3,1527-1531

So, L., \& Lee, C. H. (2013). A Case Study on the Effects of an L2 Writing Instructional Model for BlendedLearning in Higher Education. Turkish Online Journal of Educational Technology-TOJET, 12(4), 1-10.

Srijongjai, A. (2013). Collaborative feedback in a blended learning environment A case study of an EFL writingclass. The Asian Conference on Society, Education, and Technology 2013: Official Conference Proceedings Osaka, Japan.

Sultan, N. (2010). Cloud computing for education: A new dawn? International Journal of Information Management, 30 (2),109-116.

Tompkins, Gail E. (2006) Literacy for the 21st Century: A Balanced Approach. (4 ${ }^{\text {th }}$ Ed.)Boston: Pearson

Vaughan, N. D. (2010). A blended community of inquiry approach: Linking student engagement and course redesign. The Internet and Higher Education, 13,60-65

Vygotsky, L. (1978). Interaction between learning and development. Readings on the development of children, 23(3), 34-41. 
Yakhontova, T. V. (2003). English academic writing: For students and researchers. USA: New York: Longman.

Wu,Q.,(2017). A Blended Learning Strategy for Professional EnglishCourse in a Cloud Learning Environment. International Journal of Information and Education Technology, 7, (8).

Zemach, D. E and Rumisek, L. A. (2005). Academic Writing: from paragraph to essay. MacMillian.

Zhu,C.(2012).Student satisfaction, performance, and knowledge construction in online collaborative learning. Journal of Educational Technology \& Society, 15, 127-136. 